\title{
Measuring Customer loyalty on New Consumer Products through Customer Satisfaction in Jakarta Indonesia
}

\author{
Joseph MJ Renwarin \\ Institut Teknologi dan Bisnis Kalbis \\ (Kalbis Institute) Jakarta, Indonesia
}

\begin{abstract}
The quality of a product has an important role in creating customer loyalty and customer satisfaction. The purpose of this study is to determine the effect of product quality on customer loyalty with customer satisfaction as a mediating variable through a survey on Advan consumers in Jakarta. This research is a quantitative research using causal method. The population in this study is the buyers of Advan smartphone, with the sample as many as $\mathbf{2 5 0}$ chosen by the sampling technique using Lemeshow formula. Data is collected by means of questionnaires. The results indicate that product quality significantly influences customer loyalty; product quality also has a significant effect on customer satisfaction; and customer satisfaction significantly influences loyalty, or in the other words, customer satisfaction can mediate the influence of product quality on customer loyalty.
\end{abstract}

Keywords: Customer Loyalty, Customer Satisfaction, Product Quality, New Product

\section{INTRODUCTION}

The tight competition of smartphone business in Indonesia makes all companies continuously innovate by producing smartphones with high specification but at low cost. This makes difficult for the business players to get high profit. However, in the midst of smartphone competition in Indonesia, there is a brand of smartphone from Tiongkok which speculates by presenting smartphones with affordable price but having high specification. It is Advan.

Not only in innovation, but Advan also focuses on prioritizing the quality of its products. According to Kotler and Armstrong (2012: 283), the meaning of product quality is the ability of a product to perform its function, including its durability, reliability, precision, ease of operation and repair, and other valued attributes.

The success of Advan in Indonesia is proven by the sales for the last two years. In September 2014, as many as 5,000 units of Advan were sold. The explanation states that the high consumer interest is reflected by the high sales volume and its acceptance in the marketplace. However, there is a gap between the published opinion of management and the opinion outside the company. Based on the survey of American Consumer Satisfaction Index (ACSI), the brand of Advan is not included in the category of customer satisfaction). 


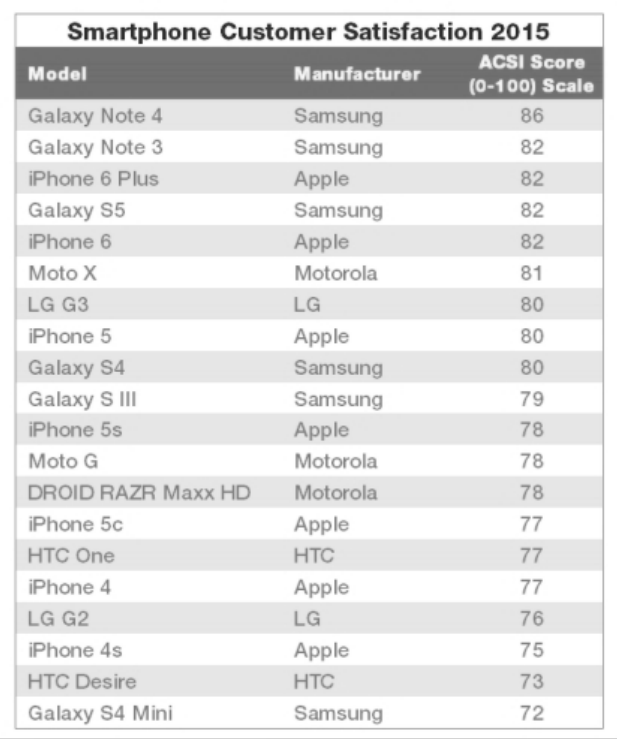

Figure 1 Customer Satisfaction Index of Smartphone 2015 According to ACSI

From the gap phenomenon it is seen that customer loyalty is important. Customer loyalty can grow because of the satisfaction generated by the use of a product. Therefore, companies should continuously develop and care about the customer satisfaction.

In this case, the success of a company is not only seen from customer satisfaction due to its product quality. Customer satisfaction will result in customer loyalty. It is because if a consumer has been satisfied with a product of a brand, then he will be loyal to the product. Thus he will repurchase and perhaps recommend his family members or friends to buy and use the product.

The problems in this study are formulated as follows:

1. Does product quality significantly influence customer loyalty?

2. Does product quality significantly influence customer satisfaction?

3. Does customer satisfaction significantly influence customer loyalty?

\section{BIBLIOGRAPHICAL REVIEW}

Marketing is an art and science in selecting and finding target market, maintaining as well as developing the growth of consumer through the activities of creating, providing, and communicating the excellence of consumer value (Kotler and Keller, 2012: 27). Marketing is a mix of interrelated activities to know the needs of consumers through creating, offering as well as exchanging valuable products and services and also developing promotion, distribution, service and price in order that the consumer needs can be well satisfied at a certain profit level. (Oentoro, 2012:2). By many literatures, the author reviewed that marketing is processes how to delivery the value proposition to customer. The process of delivering value to customer from the need and wants of customer, market demand and evaluate based on the changing of market and consumer behavior.

\section{Product Quality}

According to Kotler and Armstrong (2012: 283) the meaning of product quality is the ability of a product to perform its functions, it includes the product's overall durability, reliability, precision, ease of operation and repair, and other valued attributes. Many literatures had many dimension of the quality of product but the author reviewed that the quality of a product has eight dimensions of measurement which consist of the following aspects: 
Performance: the market operation characteristics of a product, for example, the speed of express package delivery, the colour sharpness of a TV, and the cleanliness of foods in a restaurant.

Features: the special complementary characteristics that can add the experience of consuming a product, for example, free drink during on flight, and extra collection of various dial tones in mobile phone.

Reliability: the probability of product failure or damage during a certain period of time. The less pobablity of damage, the more reliable the product.

Conformance: the conformance level of a product with the standard, for example, the punctuality of train departure and arrival, and the conformance between the size of shoes and the prevailing standard.

Durability: the number of product usage before it should be changed. The higher frequency of possible normal usage the higher durability of the product will be. Battery is an example of product that frequently emphasizes the aspect of durability as a key positioning.

Service ability: the speed and ease of repair as well as the competence and hospitality of service staff.

Aesthetics: it concerns the product appearance that can be assessed using five senses (taste, aroma, sound, and so on).

Perceived quality: the quality perceived based on the reputation of the seller, for example, BMW car, Rolex watch, Polo shirt, and Sony electronic appliances.

\section{Customer satisfaction}

Acording to Kotler (2009: 138), customer satisfaction is the someone's feeling of being contented or disappointed that rises after comparing the expectation with the reality. High satisfaction or contentment generates emotional bound with the brand or company. According to Hasan (2013: 108), the strategies to enhance customer satisfaction. The strategy of Superior Product Quality; the company who wants to implement customer satisfaction program should have products with good quality and prime services.

The author reviewed that the strategy should focusing on the primary customers; the company focusing on customer can obtain 20 percent of the customers who routinely consume 80 percent of product sales.

\section{Customer loyalty}

Customer loyalty is the customer's commitment to a brand, based on the very positive attitude and reflected in the consistent repeat purchase (Tjiptono 2012: 482).

The dimensions of customer loyalty according to Kotler and Keller (2012: 57) are repeat purchase (loyalty in purchasing product), retention (ketahanan against negative influence concerning the company), referrals (totally referring the compnay's existence).

According to Hasan (2013: 121), customer loyalty on a brand is one of the brand assets, indicating the high value of loyalty because many challenges should be faced in order to 
develop it and it takes very long time. However, the customer loyalty that is built will give many benefits to the company, for example:

Reducing marketing cost. Loyal customer may reduce marketing cost. Some researches show that the cost for getting new customers is six times bigger than the cost for retaining the existing customers.

Trade Leverage, brand loyalty provides trade leverage for companies. A product with the brand having loyal customers will attract distributors to give wider space than other brands in the same store.

Attracting new customers; a customer who is satisfied with the brand he bought can influence other consumers, while a customer who is not satisfied will tell his dissatisfaction to eight to 10 other people.

Responding competitors' threats; brand loyalty enables a company to have time to respond the acts done by the competitors.

The author reviewed that the cumulative value of sustainable business; efforts to retain customers and loyalty on the company's product along customer lifetime value, by providing the products that are constantly and regularly needed.

\section{Research Method}

In this research, the research method used is causal method which is the cause and effect relationship. Thus, there will be independent variables (that influence) and dependent variable (that is influenced). The Causal method is how a variable influences other variables.

The specific population are the buyers of Xiaomi smartphone product. The sample will be taken using nonprobability sampling technique, that is sampling technique which does not give the same opportunity for every element or member of the population to be selected as sample. The technique for selecting sample uses purposive sampling, that is a sampling technique with certain considerations. The researchers use purposive sampling because this study uses certain considerations or objectives to select the respondents corresponding with the research problem in order to obtain accurate data. The sample in this study are partly from the consumers of Xiaomi smartphone in Jakarta. The number of population is not exactly known in this study, so the sampling technique uses Lemeshow formula (Ikhsan, 2013: 44):

$\mathrm{n}=$ number of Sample

$$
n=\frac{\mathrm{p}(1-\mathrm{p})\left(\frac{\mathrm{Z} \alpha}{2}\right)^{2}}{\mathrm{D}^{2}}
$$

$\mathrm{Z}=$ Confidence level of the sample needed in the research, at $\alpha=5 \%$ (confidence level is set $95 \%)$ then $\mathrm{z}=1.96$

$\mathrm{P}=$ the case proportion examined in the population, if $\mathrm{p}$ is not known use the biggest $\mathrm{p}$. The biggest $\mathrm{p}$ is $\mathrm{p}=0.5$

$\mathrm{D}=$ Precision/error level used is $5 \%$

\section{Types and Sources of Data}

The Quantitative data is the research method used to review certain populations or samples, data collection uses research instrument, data analysis is quantitative/statistical, in order to examine the hypothesis that has been determined. The data measured in this study uses a numeric scale (number), such as:

Interval scale, data is measured using the distance of two points at the identified scale. 
Likert scale, it is used to measure the attitude, opinion, and perception of someone or a group of people related to social phenomena. In likert scale, the variable that will be explained become a variable indicator. The indicator becomes a starting point to formulate the instrument in the fom of questions. The answer of each question item Jawaban using likert scale has some levels from very positive up to very negative.

The primary data in this research is obtained through distributing questsionaire to the respondents of Xiaomi smartphone users. The answer of respondents is taken as primary data to obtain the information about Advan smartphone.

\section{Research Model}

The following is the research model in this study:

Dependent variable symbolized by $(\mathrm{Y})$ is the variable influenced or which becomes the effect due to the existence of independent variable. In this study, the dependent variable is customer loyalty (Y1).

Independent variable symbolized by $(\mathrm{X})$ is the variable which influences or which becomes the cause of the dependent variable occurence. In this study, the independent variable is product quality (X1).

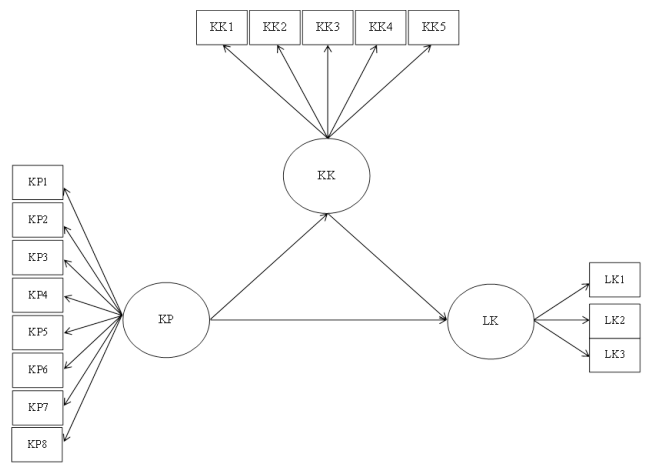

Intervening variable is the variable which theoretically influences the relationship between independent variable and dependent variable to become an indirect relationship and can not be observed and measured. This variable is a mediating variable positioned between independent variable and dependent variable, so that independent variable indirectly influences the change or occurence of dependent variable. In this study, the intervening variable is customer satisfaction (M1).

\section{Path Analysis}

The analysis tool used for data processing to examine the hypothesis is path analysis through SPSS 18 program. Path analysis is a research method which is mainly used to examine the strength and direct as well as indirect relationship among various variables. Path analysis also estimates the size of influence between a variable and the other variables in a causal hypothesis.

\section{A. Characteristics of Respondents}

\section{DISCUSSION}

The data of respondent distribution by sex, it can be found that most respondents are mall. The percentage of male respondents ia as many as $91 \%$ and female respondents is $9 \%$ of the total respondents. This percentage of respondents who have smartphone Advan is more than male. Therefore, the company of Advan reflects itself as masculine rather than feminim. 
The characteristic of age the most using Advan smartphone, that is $15-25$ years as many as $66 \%$ (165 people), followed by age of $26-35$ years as many as $26 \%$ ( 65 people), age of $>35$ years as many as $7 \%$ (18 people), and the last is age of < 15 years as many as $1 \%$ (2 people). Therefore, it can be decided that the age of 15-25 years is the most use Advan smartphone and the researcher indicates the age of 15-25 years can be categorized as having been adolescence because they tend to use smartphone to play games, so Advan smartphone is suitable for those who choose smartphone with high specifications.

The characteristic of occupation the most using Advan smartphone, that is students/college students as many as 49\% (122 people), followed by private employees $35.6 \%$ (90 people), entrepreneurs $8.9 \%$ (17 people), civil servants $6 \%$ (15 people), and the last housewives $0.4 \%$ (2 people). Therefore, it can be concluded that the occupation the most using Advan smartphone is students/college students and the researcher indicates that students or college students using Advan smartphone are those whose parents buy the smartphone for them.

The info about how many times the consumers buy Advan smartphone, the characteristic of those who buy only once indicates the percentage of $61 \%$ (153 people), who have bought twice indicates the percentage of $23 \%$ (58 people), and those who have bought $>$ twice indicates the percentage of $18 \%$ ( 45 people). Therefore, it can be concluded that the characteristic of those who buy Advan smartphone once is because the product is newly known.

The respondent datas of Advan smartphone type being used. From 250 respondents using Advan brand, the handphone used by the consumers in Jakarta spread evenly, meaning that male adolescences (boys) is not vulnerable of brand.

\section{B. Validity Test}

In this study, validity test is carried out by seeing $r$ table which is 0.0928 with 2 -sided test and number of respondents (n) $257-2=250$. Therefore, data can be said as valid if the total value of Pearson Correlation is more than the value of $r$ table that is 0.0928 .

The value of total pearson correlation in Table 1 of product quality dimension, Table 2 of customer loyalty, and the Table of customer satisfaction are bigger than the value of $r$ table, that is 0.0928 so that all the dimensions in this study are considered as valid.

\section{Reliability Test}

Table 4 Reliability Test

\begin{tabular}{ccl}
\hline Variable & Cronbach Alpha & Remarks \\
\hline Product Quality & 0.946 & Reliable \\
\hline Customer loyalty & 0.922 & Reliable \\
\hline Customer satisfaction & 0.944 & Reliable \\
\hline
\end{tabular}

Table 4 shows that the indicators of product quality, customer loyalty, and customer satisfaction are said to be reliable because of having the value of Cronbach Alpha more than 0.60 . 


\section{T Test}

\begin{tabular}{clccc}
\multicolumn{4}{c}{ Table 5 T Test } & \\
Hipotesis & \multicolumn{1}{c}{ Deskriptif } & T tabel & Nilai t & Keterangan \\
\hline H1 & $\begin{array}{l}\text { Kualitas produk } \\
\text { berpengaruh terhadap } \\
\text { loyalitas konsumen }\end{array}$ & 1,965 & 9,677 & Diterima \\
\hline H2 & $\begin{array}{l}\text { Kualitas produk } \\
\text { berpengaruh terhadap } \\
\text { kepuasan konsumen }\end{array}$ & 1,965 & 28,548 & Diterima \\
\hline H3 & $\begin{array}{l}\text { Kepuasan konsumen } \\
\text { berpengaruh terhadap } \\
\text { loyalitas konsumen }\end{array}$ & 1,965 & 6,278 & Diterima \\
\hline
\end{tabular}

Table 5 shows that the variable of product quality is said to significantly influence customer loyalty, because the value of $t$ calculation $9.677>t$ table 1.965. The variable of product quality is said to significantly influence customer satisfaction, because the value of $t$ calculation 28.548 $>t$ table 1.965. The variable of customer satisfaction is said to significantly influence customer loyalty because the value of $\mathrm{t}$ calculation $4.278>\mathrm{t}$ table 1.965 .

\section{E. Path Analysis}

The multiple regression model in this study is as follows:

$$
\mathrm{Y}=\mathrm{a}+\mathrm{b}_{1} \mathrm{X}_{1}+\mathrm{b}_{2} \mathrm{X}_{2}+\ldots+\mathrm{b}_{\mathrm{n}} \mathrm{X}_{\mathrm{n}}
$$

The equation is as follows:

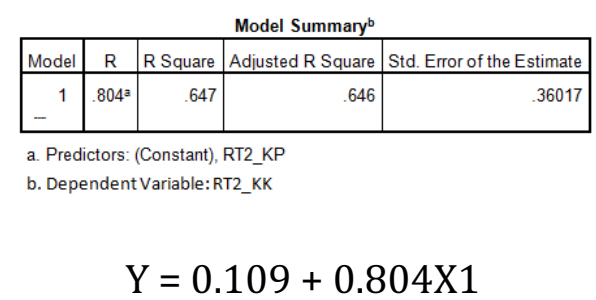

The equation above means that the customer loyalty is influenced amounting 0.804 or $80.4 \%$ of the product quality variable.

Structural equation 2 , that is $\mathrm{Y} 1=0.157+0.492 \mathrm{KP}+0.319 \mathrm{KK}$, means that the customer loyalty is influenced amounting 0.492 or $49.2 \%$ of the product quality variable and customer loyalty is influenced amounting $31.9 \%$ of the product quality variable. This indicates that if customer loyalty is only measured using product quality variable, then the result obtained is very big or absolute; but if another variable is added as a mediating variable, then the value of product quality variable only indicates little value. If other variables supporting this study, such as brand image, purchase decision, price, etc., then product quality variable will indicate less value. It is because customer loyalty is regarded not only from product quality but also many other factors that can support the creation of customer loyalty. With just satisfaction, consumers will have loyalty on a brand.

Result of Multiple Regression Analysis on Product Quality against Customer loyalty with Satisfaction as Intervening Variable

\begin{tabular}{|c|c|c|c|c|}
\hline \multicolumn{5}{|c|}{ Model Summary } \\
\hline Model & $\mathrm{R}$ & R Square & Adjusted R Square & Std. Error of the Estimate \\
\hline 1 & $.772^{\mathrm{a}}$ & .595 & .594 & .40612 \\
\hline
\end{tabular}


In the path of product quality, customer satisfaction against customer loyalty, the value of $r$ square is 0.595 or $59.5 \%$. This point means that the variables of product quality, customer satisfaction against the variable of customer loyalty has influence amounting $59.5 \%$ while the rest $40.5 \%$ is influenced by other variables, such as brand image, purchase decision, price, and so on.

Based on the previous research and analysis, the results of this study are found as follows:

1. Product quality significantly influences customer loyalty, meaning that the better the quality of a product the higher the customer loyalty; this can create customer loyalty.

2. Product quality significantly influences customer satisfaction, meaning that the better the quality of a product this can create customer satisfaction.

3. Customer satisfaction significantly influences customer loyalty, meaning that the higher the customer satisfaction, the higher customer loyalty will be created.

\section{BIBLIOGRAPHY}

Adam, M. (2015). Theory and application of Marketing Management Services. Bandung: Alfabeta.

Akhmad, J. (2015). Marketing Aplication and Salesmanship. Jakarta: Lentera Ilmu Cendekia.

Ardi, A. N. (2014). The impact of product quality of Smartphone Samsung Android bases to customer satisfaction in using Samsung Galaxy S4 (the Study in Bandung Year 2014). Manajemen Bisnis.

Assauri, S. (2012). Strategic Marketing: Sustaining Lifetime Customer Value. Jakarta: Rajawali Pers.

Atsatalada, N. dan Mudiantono. (2012). Analisis of impact service quality to customer satisfaction and impact on customer loyalty for using transporter service PO Sumber Alam. (case Study to passenger bus bus Sumber Alam destination Yogyakarta-Jakarta). Jurnal Manajemen. Volume 1, Nomor 1.

Beladin, M. I. dan Dwiyanto, B. M. (2013). Analisis Pengaruh Kualitas Produk, Kualitas Pelayanan dan Citra Merek terhadap Kepuasan Konsumen (Studi pada Pengguna Sepeda Motor Merek Yamaha dari Kalangan Mahasiswa Universitas Diponegoro Semarang). Jurnal Manajemen.

Ghozali, I. (2016). Aplikasi Analisis Multivarite dengan SPSS IBM 23, Semarang: Badan Penerbit Universitas Diponegoro.

Hasan, A. (2013). Marketing dan Kasus-Kasus Pilihan. Yogyakarta: Center for Academic Publishing Service.

Hermawan, B. (2011). Kualitas Produk terhadap Kepuasan, Reputasi Merek dan Loyalitas Konsumen Jamu Tolak Angin PT. Sido Muncul. Jurnal Manajemen Teori dan Terapan

Hutomo, A. S. (2011). Pengaruh Kualitas Produk dan Tingkat Kepuasan Konsumen terhadap Loyalitas Pelanggan Pada Produk Makanan Tela Krezz Cabang Bekasi. Jurnal Manajemen.

Ikhsan, M (2013) Metodelogi Penelitian. Purwokerto UNSOED Press.

Irawan, Ddan Japarianto, E. (2013). “Analisa Pengaruh Kualitas Produk terhadap Loyalitas melalui Kepuasan sebagai Variabel Intervening pada Pelanggan Restoran Por Kee Surabaya”. Jurnal Manajemen Pemasaran. Vol. 1, No. 2 .

Kotler, P dan Amstrong, G. (2012). Prinsip-prinsip Pemasaran, Edisi 13. Jilid 1. Jakarta: Erlangga.

Kotler, P dan Keller, K. L. (2009). Manajemen Pemasaran. Edisi 13. Jilid 1. Jakarta: Penerbit Erlangga.

Kotler, P. (2009). Marketing Management: An Asian Perspective, Fifth Edition. Jakarta: Erlangga.

Kotler, P dan Keller, K. L. (2012). Marketing Management 13. New Jersey: Pearson Prentince Hall, Inc.

Latan, H. (2010). Analisis Multivariate Teknik dan Aplikasi Menggunakan Program IBM SPSS 20.0. Bandung: Alfabeta.

Latan, H. (2012). Structural Equation Modeling, Konsep dan Aplikasi. Bandung: Alfabeta.

Martono, N. (2011). Metode Penelitian Kuantitatif: Analisis Isi dan Analisis Data Sekunder. Jakarta: Raja Grafindo Persada.

Oentoro, D. (2012). Manajemen Pemasaran Modern. Yogyakarta: Laksbang Pressindo. 
Ratna Sari, S. (2013). Kualitas Pelanggan, Kepercayaan Pelanggan dan Switching Barriers Terhadap Loyalitas Pelanggan Hartono Elektronika Surabaya. Jurnal Manajemen Pemasaran.

Saidani, B dan Arifin, S. (2012). Pengaruh Kualitas Produk dan Kualitas Layanan Terhadap Kepuasan Konsumen dan Minat Beli pada Ranch Market. Fakultas Ekonomi.

Sandjojo, N. (2011).Metode Analisis Jalur (Path Analysis) dan Aplikasinya. Jakarta: Pustaka Sinar Harapan.

Sarjono, H \& Julianita (2011). SPSS vs LISREL Sebuah Pengantar Aplikasi Untuk Riset. Cetakan kedua. Jakarta: Salemba Empat.

Sembiring, I. J et al. (2014). Pengaruh Kualitas Produk dan Kualitas Pelayanan terhadap Kepuasan Pelanggan dalam Membentuk Loyalitas Pelanggan (Studi pada Pelanggan McDonald's MT Haryono Malang). Jurnal Ilmu Administrasi.

Sudarmanto, Gunawan R. (2013). "Statistik Terapan Berbasis Komputer dengan Program IBM SPSS Statistics 19”. Jakarta: Mitra Wacana Media.

Sudaryono. (2014). Perilaku Konsumen: Dalam Perspektif Pemasaran. Jakarta: Lentera Ilmu Cendekia.

Wulandari, N. dan Mudiantono. (2013). Analisis Pengaruh Kualitas Produk, Kualitas Pelayanan dan Lokasi terhadap Kepuasan Konsumen (Studi Kasus Pada Konsumen Kopikita Semarang). Jurnal Manajemen.

\section{Website}

Antutu. “Antutu Report: TOP 10 Performance Smartphones, Q1 2016". 2016. [Online]. Accessed on 16 April 2016 from http://www.antutu.com/en/view.shtml?id=8216.

Tokopedia. "Rentang Harga Apple iPhone 6s - GSM - 64 GB". 2016. [Online]. Accessed on 24 February 2016 from https://www.tokopedia.com/catalog/50389/apple-iphone-6s-gsm-64-gb.

Tokopedia. "Rentang Harga Samsung Galaxy S7 edge”. 2016. [Online]. Accessed on 24 February 2016 from https://www.tokopedia.com/catalog/50761/samsung-galaxy-s7-edge.

Tokopedia. "Rentang Harga Samsung Galaxy J3”. 2016. [Online]. Accessed on 1 July 2016 from https://www.tokopedia.com/catalog/50767/samsung-galaxy-j3-2016

Tokopedia. "Rentang Harga Xiaomi Redmi Note 2". 2016. [Online]. Accessed on 24 July 2016 from https://www.tokopedia.com/catalog/50241/xiaomi-redmi-note-2

Tokopedia. "Rentang Harga Oppo Neo 7". 2016. [Online]. Accessed on 24 July 2016 from https://www.tokopedia.com/catalog/50584/oppo-neo-7

Tabloid Pulsa. "Survei Kepuasan Pelanggan, Ranking iPhone 6 di Bawah Galaxy Note 4". 2015. [Online]. Accessed on 24 July 2016 from https://www.tabloidpulsa.co.id/news/21576-survei-kepuasan-pelanggan-ranking-iphone6-di-bawah-galaxy-note-4

Techinasia. "Bagaimana Xiaomi Memenangkan Hati Konsumen Indonesia”. 2015. [Online]. Accessed 24 February 2016 from https://id.techinasia.com/xiaomi-indonesia-meluncurkan-website-resminya

Wijaya, K. K. "Bagaimana Xiaomi Memenangkan Hati Konsumen Indonesia”. [Online] Accessed 20 February from https://id.techinasia.com/bagaimana-xiaomi-laris-di-indonesia. 